\title{
Model for Predicting the Initial Solution pH at Pre-Assumed Final pH and Concentration of Dissolved Zinc during Leaching of Galena in Butanoic Acid Solution
}

\author{
C. I. Nwoye \\ Department of Materials and Metallurgical Engineering, Federal University of Technology, \\ Owerri, Nigeria.
}

\section{Contact: chikeyn@yahoo.com}

\section{ABSTRACT}

Model for predicting the initial solution $\mathrm{pH}$ at pre-assumed final $\mathrm{pH}$ and concentration of dissolved zinc, during leaching of galena in butanoic acid solution has been derived. The model;

$$
\alpha=\left(\frac{1.4 \gamma}{\ln \left[(\mathrm{Zn})^{1 / 3}\right]}\right)
$$

shows that the initial pH of the leaching is dependent on the values of the pre-assumed final solution $\mathrm{pH}$ and concentration of dissolved zinc. The validity of the model was rooted in the expression $e^{N(\gamma / \alpha)}={ }^{3} \sqrt{Z n}$ where both sides of the expression were approximately equal to 4 . The respective deviation of the model-predicted initial solution $\mathrm{pH}$ value from that of the corresponding experimental value was less than $2 \%$ which is quite within the acceptable deviation limit of experimental results.

Keywords: Model, Prediction, pH, Butanoic Acid, Galena, Leaching.

\section{INTRODUCTION}

It has been discovered [1] that the lead-zinc deposit of Nigeria especially Ishiagu-Abakiliki area of telethermal type originated from low temperature hydrothermal solutions associated with tertiary to recent volcanism. They have been confined to vertical fracture zones in shale's and mudstone and to a lesser extent in sand stone. The ore mineral was found [1] to be galena and sphalerite accompanied by some chalcopyrite and secondary pyromorphite, anglesite and crussite and the gangue is chiefly quartz with some siderite and marcarsite. In the Abakiliki zone, the 
lead-zinc deposit is due to dense hydrothermally heated connate brine from temperature of 100$160^{\circ} \mathrm{C}$. At this temperature, the brine-rich chlorides from sediments and metals from clay and feldspar combine with sulphur to form the sulphide [1]. The mineral deposit of Ishiagu-Nigeria consists of galena $(\mathrm{PbS})$ and sphalerite $(\mathrm{ZnS})$. It is estimated to consist about $75 \%$ of the total deposit with minor pyrite $(\mathrm{FeS})$, chalcopyrite $(\mathrm{CuFeS})$, siderite $\left(\mathrm{FeCO}_{3}\right)$ and quartz $\left(\mathrm{SiO}_{2}\right)$. The chemical and mineralogical composition of the ore are thus: $\mathrm{PbS}(45.84 \%), \mathrm{ZnS}(30.63 \%), \mathrm{SiO}_{2}$ (9.96\%), $\mathrm{FeS}(5.49 \%), \mathrm{CuFeS}(4.38 \%)$ and $\mathrm{FeCO}_{3}(3.63 \%)$ [2].

A feasibility study [3] on the extraction of lead from Ishiagu lead-zinc ore has been carried out with the view to knowing the possibility of extracting lead from Ishiagu galena using different acid types. The results of the investigation reveal that the weight concentration of lead after leaching with dilute nitric acid, sulphuric acid and aqueous solution of both acids are $39.5 \% \mathrm{w} / \mathrm{w}$, $14.16 \% \mathrm{w} / \mathrm{w}$ and $15.18 \% \mathrm{w} / \mathrm{w}$ respectively. These results indicate that nitric acid gave the best result of recovery $(84.2 \%)$, with original lead in the ore being $46.9 \% \mathrm{w} / \mathrm{w}$.

It has been suggested [4] that flotation of sphalerite could be carried out using some imported reagents and fuel oil, using a method of recovery called froth flotation. This method was found to utilize the difference between the physico-chemical surface properties of a mineral. This conclusion followed a research carried out by Onyemaobi [4] to evaluate the flotation performance of Nigeria's sphalerite from lead-zinc ore with particular reference to the Ishiagu lead-zinc ore. It has been discovered [5] that most lead-zinc ores are fine grained and are concentrated mainly by flotation. The flotation results obtained in this work (Ishiagu ore inclusive) are that the factors affecting flotation includes (1) Degree of oxidation (2) Abundance in nature of iron sulphide and nature of a non-sulphide gangue [5] Galena was found [6] to float in slightly alkaline medium (pH9-10) with short-chain xanthates (potassium ethyl xanthates; isopropyl xanthates). In addition to this, it was discovered that at the critical $\mathrm{pH}$ of 10.4 when ethyl xanthate is used, usage of lime would make it behave like a depressant [6]. Investigation on the role of $\mathrm{pH}$ on flotation of sphalerite from Ishiagu lead-zinc ore has been carried out. The result of the investigation reveals that if there are no activator ions in the medium, sphalerite does not float with xanthate and dithiophosphate collector. Activation and flotation of sphalerite in acid medium ( $\mathrm{pH} 4-5)$ is performed with $\mathrm{As}, \mathrm{Sb}$, and $\mathrm{Pt}$ ions and in neutral conditions ( $\mathrm{pH}$ 6.87.3) $\mathrm{Ce}, \mathrm{Pb}, \mathrm{Cu}, \mathrm{Cd}, \mathrm{Ag}, \mathrm{Hg}, \mathrm{B}$ and $\mathrm{Au}$ ions became effective [7].

It has been discovered [8] that during bioleaching of Ishiagu lead-zinc ore, using mixed cultures of Acidithiobacillus Ferrooxidans, Acidithiobacillus Thiooxidans and Leptospirillum Ferrooxidans, higher silica contents of the ore reduce acidity, iron mobility and oxidation. It was also found [9] during the leaching of zinc and copper out from their respective sulphide ore that the concentrations of zinc and copper formed reduced as particle size decreased while silica, sulphur, iron and lead contents increased. Also leaching rate of copper was found to be lower than zinc. Results of sedimentation analysis carried out by Nwoye [10] indicate that the average grain size of Ishiagu galena concentrate is approximately $100 \mu \mathrm{m}$. He also found that the mechanism of bioleaching of Ishiagu galena concentrates was indirect mechanism. This was sequel to the dominance of $\mathrm{Fe}^{3+}$ ions over $\mathrm{H}^{+}$during the leaching process. The best operating conditions for the highest yield of $\mathrm{Pb}$ were found to be; leaching temperature of not less than 
$32^{0} \mathrm{C}$, starting $\mathrm{pH}$ of leaching solution in the range $1.8-2.0$, concentration of $\mathrm{Fe}^{2+}$ in the starting leaching solution: $2 \mathrm{~g} / \mathrm{dm}^{3}(0.007 \mathrm{M})$, grain size of ore to be leached: $0.063 \mu \mathrm{m}$, mixed culture of Acidithiobacillus Ferrooxidans (ATF), Acidithiobacillus Thiooxidans (ATT) and a newly discovered bacteria (CBT). The microorganisms, Acidithiobacillus Ferrooxidans are able to oxidize ferrous ions and the reduced sulphur compounds [11] while Acidithiobacillus Thiooxidans are able to oxide only reduced sulphur compound summarized by the reaction[12,13].

$$
\begin{gathered}
2 \mathrm{Fe}^{2+}+2 \mathrm{H}^{+}+0.5 \mathrm{O}_{2}+\text { bacteria } \longrightarrow 2 \mathrm{Fe}^{3+}+\mathrm{H}_{2} \mathrm{O} \\
\mathrm{S}^{2-} \longrightarrow \mathrm{S}^{0} \longrightarrow \mathrm{S}_{2} \mathrm{O}_{3}{ }^{2-} \longrightarrow \mathrm{S}_{4} \mathrm{O}_{6}{ }^{2-} \longrightarrow \mathrm{SO}_{3}{ }^{2-} \longrightarrow \mathrm{SO}_{4}{ }^{2}
\end{gathered}
$$

Researchers [14] discovered that arsenic can be reduced in a complex galena concentrate by Acidithiobacillus Ferrooxidans. The results of the investigation reveal that arsenopyrite was totally oxidized. The sum of arsenic remaining in solution and removed by sampling represents from 22 to $33 \%$ in weight (yield) of the original content in the mineral. The rest of the biooxidized arsenic form amorphous compounds that precipitate galena $(\mathrm{PbS})$ was totally oxidized too, anglesite $\left(\mathrm{PbSO}_{4}\right)$ formed is virtually insoluble and remains in the solids. The influence of seven factors in a batch process was studied. The maximum rate of arsenic dissolution in the concentrate was found using the following levels of factors; small surface area of particle exposure; low pulp density, injecting air and adding the leaching medium to the system. It was also found that ferric chloride and carbon dioxide decreased the arsenic dissolution rate. Bioleaching kinetic data of arsenic solubilization were used to estimate the dilution rate for a continuous culture. Calculated dilution rates were relatively small (0.88 0.103 day $\left.^{-1}\right)[14]$.

It has been found [15] that the leaching rates of single sulphide minerals decreased in the order pyrite $>$ sphalerite $>$ galena $>$ chalcopyrite, with the rate of pyrite dissolution being of a similar magnitude to the highest values reported previously [15]. The leaching rates of galena, chalcopyrite and sphalerite increased by factors of 31, 18 and 1.5, respectively, in the presence of pyrite, due to its superior catalytic properties. In the galena + pyrite experiment, the concentration of $\mathrm{Fe}$ did not increase appreciably between the first and final sampling times, whilst the $\mathrm{Pb}$ concentration did increase significantly. Hence, galvanically promoted dissolution of galena + pyrite decreases the pyrite electrode potential and its dissolution rate. Also in the galena + pyrite experiment, $75 \%$ of the total $\mathrm{S}$ in solution as measured by ICP -AES was detectable by HPLC, which detects only anionic species; this could be due to the presence of colloidal elemental S [15]. Acid leaching of lead sulphide has been investigated [16]. The results of the investigation indicate that prior to mineral addition, the redox potential of the acid solutions was $360 \pm 10 \mathrm{mV}$ (SHE). On addition of the mineral powders, the value changed rapidly. In most cases, the redox potential then decreased by a few tens to a hundred or more $\mathrm{mV}$ to reach a stable value, except for the single-phase galena + pyrite mixture, for which the redox potential rose continuously throughout the experiment. The ranges of redox potential at $\mathrm{pH}$ 2.5 recorded for each single mineral sample are plotted onto the potential $\mathrm{pH}$ diagram for the $\mathrm{S}-$ $\mathrm{H}_{2} \mathrm{O}$ system. Although the $\mathrm{pH}$ of the leach solution was kept constant, the generation or consumption of protons could be determined by monitoring the volume of acid needed to maintain a $\mathrm{pH}$ of 2.5. Dissolution of oxidation products formed during grinding of galena 
produced dissolved $\mathrm{Pb}$ (II) and sulphur concentrations significantly higher than in the case of sphalerite leaching. However, concentrations of both species decreased over the first hour of the experiment, probably due to restricted solubility of $\mathrm{PbCl}_{2}$ and $\mathrm{PbSO}_{4}$, the latter phase having a particularly low solubility product $\mathrm{Ksp}\left(\mathrm{PbSO}_{4}\right)=10^{-7.86}$. The equations of the reactions involved are as follows.

$$
\begin{aligned}
& (1-\mathrm{y})\left(\mathrm{PbS}+4 \mathrm{Cl}^{-} \longrightarrow \mathrm{PbCl}^{2-}{ }_{4}+\mathrm{S}+2 \mathrm{e}^{-}\right) \\
& \mathrm{y}\left(\mathrm{PbS}+4 \mathrm{Cl}^{-}+4 \mathrm{H}_{2} \mathrm{O} \longrightarrow \mathrm{PbCl}^{2-}{ }_{4}+\mathrm{SO}^{2-}{ }_{4}+8 \mathrm{H}^{+}+8 \mathrm{e}^{-}\right)
\end{aligned}
$$

Though the dissolved metal to sulphur ratios were not as high as in the case of sphalerite leaching, they increased from $1.3(\mathrm{y}=0.7)$ after $19 \mathrm{mins}$ to $2.5(\mathrm{y}=0.4)$ after $182 \mathrm{~min}$. Based on the XPS data, no significant changes in $\mathrm{S}$ speciation occur at the surfaces of these minerals as a result of atmospheric oxidation and acid leaching. Elemental $S$ has been reported [17] at the surfaces of both air oxidized and acid-leached galena but no evidence for the presence of elemental S was obtained here possibly due to the sulphur desorption in UHV chamber of the instrument, which had no low - temperature range [16].

Lead sulphide is rapidly attacked by ferric ion over a wide range of conditions. Soluble lead chlorocomplexes as well as ferric and ferrous chlorocomplexes are formed. It is to be expected after all, that the various metal chlorocomplexes would play an important role in the leaching reaction mechanism. In addition, it is clear from the result of previous workers that the effect of $\mathrm{Fe}^{3+}, \mathrm{Cl}^{-}$and $\mathrm{H}^{+}$are coupled, and that the reaction kinetics and the mechanism of ferric chloride leaching of PbS have not been clearly established [18]. Rapid parabolic kinetics were observed in this study under all conditions and it was shown that the parabolic rate constant was directly proportional to the area of galena being leached. In the presence of ferric ion, the rate was insensitive to $\mathrm{HCl}$ concentrations $<3.0 \mathrm{M}$, but increased rapidly at higher acidities because of direct acid attack of the sulphide. In the absence of ferric ion, the rate increased steadily with increasing $\mathrm{HCl}$ concentrations, and linear kinetics was observed. The galena leaching rate increased as $\left(\mathrm{FeCl}_{3}\right)$ for $\mathrm{FeCl}_{3}$ concentrations in the range 0.01-0.1M, but decreased slightly with increasing $\mathrm{FeCl}_{3}$ concentrations in the range $0.1 \mathrm{M}$ to $2.0 \mathrm{M} \mathrm{FeCl}_{3}$. The rate was virtually independent of the concentration of the $\mathrm{FeCl}_{2}$ reaction product. The presence of significant amount of the $\mathrm{PbCl}_{2}$ reaction product, however, caused the galena leaching rate to decrease rapidly. A minimum leaching rate was realized in saturated $\mathrm{PbCl}_{2}$ solutions [18]. Studies [18] on the ferric chloride brine leaching of galena concentrate have been carried out. The results of the investigation reveal several advantages of ferric chloride over the reagents as a leaching media which includes that it exhibits substantially faster dissolution rates for most sulphides, it is regenerated easily by chlorination of ferrous chloride leaching by-products, and it has greater potential for the treatment of complex sulfides [18]. Further studies [19] on the ferric chloride brine leaching of galena concentrate have been carried with the view to investigating the thermodynamics and kinetics of the process. Seon-Hyo etal [19] discovered that under the leaching condition of their work, the distribution of the various metal chloro complexes is relatively insensitive to the extent of $\mathrm{PbS}$ dissolution [19]. Investigations [20] on the $\mathrm{Cl}_{2}-\mathrm{O}_{2}$ leaching of galena flotation concentrate have been done with the view to evaluating the kinetics of the process. The results of this investigation indicate that the rate of gas transfer can be 
enhanced by increasing the partial pressure of the gas and by using vigorous agitation to increase the surface area of the liquid-gas interface.

Nwoye [10] derived a model for predicting the leaching rate of lead during bioleaching of galena using different strains of bacteria such as ATF, ATT and the newly discovered bacteria (CBT and CTT). The model;

$$
\varnothing=\mathrm{e}^{-(\Upsilon+\ln \Upsilon)}
$$

referred to as $\mathrm{pH}$-model, calculates the leaching rate when the $\mathrm{pH}$ of the leaching solution is known at any instant during the leaching process.

$$
\text { Where } \begin{aligned}
\gamma & =\mathrm{pH} \text { of the leaching solution at any instant during the leaching process. } \\
\varnothing & =\text { Leaching rate of lead from galena }\left(\mathrm{g} / \mathrm{dm}^{3} \mathrm{hr}^{-1}\right)
\end{aligned}
$$

On multiplying both sides of the model by leaching time t, the model then calculates the concentration of $\mathrm{Pb}$ leached out as

$$
\Theta=\mathrm{e}^{-(\Upsilon+\ln \Upsilon)} \mathrm{t} \text {. }
$$

Nwoye [10] also derived a model (known as $\Delta \mathrm{G}$ - model) for predicting the leaching rate of lead relative to the bacterial leaching index and the free energy change associated with the bioleaching process involved. The model;

$$
\varnothing=10^{(\Delta \mathrm{G} / \mathrm{C})}
$$

calculates the leaching rate when the values of the free energy change $\Delta \mathrm{G}$, associated with the leaching reaction as well as bacterial leaching index $\mathrm{C}$, are known. This model indicates that the value of the leaching rate and concentration of leached $\mathrm{Pb}$ depends largely on the nature and leaching ability of bacteria or bacteria consortium used. It was observed that the greater the value of $\mathrm{C}$, the higher the bacterial leaching ability and tendency. It was also found that the bacterial leaching index of bacillus spp is within the range 2-2.2 while mixed cultures of bacillus spp gave greater value (close to 3 ) of $\mathrm{C}$ than the case of single bacillus spp [10]. Based on the fore going, given the values of the leaching rate and the associated free energy change, the specie of the bacteria used can be identified by calculating the value of $\mathrm{C}$, just by re-arranging the model as $\mathrm{C}$ $=\Delta \mathrm{G} / \log \varnothing$. It was observed that pseudomonas spp. of bacteria have a value of $\mathrm{C}$, less than 1 . This value was found to be associated with very poor yield of $\mathrm{Pb}$ and leaching rate. Furthermore, on multiplying both sides of the model by the leaching time $t$, the model then calculates the concentration of leached $\mathrm{Pb}$ as

$$
\Theta=\left(10^{(\Delta \mathrm{G} / \mathrm{C})}\right) \mathrm{t} .
$$

Nwoye [10] further derived a more comprehensive and precision-enhanced model by jointly associating the $\mathrm{pH}$-model and $\Delta \mathrm{G}$-model. The resultant model;

$$
\Delta \mathrm{G}=\log \left(\mathrm{e}^{-(\Upsilon+\operatorname{In} \Upsilon)}\right)^{\mathrm{C}}
$$

not only calculates both the leaching rate and concentration of leached $\mathrm{Pb}$ (though indirectly), but also calculates directly the free energy change associated with the leaching process as well as the bacterial leaching index, as the case may be providing that two of the process parameters are known. The $\mathrm{pH}$ of the leaching solution during the leaching process can also be calculated using this model. 
It has been found $[10,21]$ that the final $\mathrm{pH}$ of the leaching solution depend on the leaching time, initial $\mathrm{pH}$ for the leaching solution and the leaching temperature.

The aim of this work is to derive a model for predicting the initial solution $\mathrm{pH}$ at pre-assumed final $\mathrm{pH}$ and concentration of dissolved zinc during butanoic acid leaching of Ishiagu (Nigeria) galena. The proposed work resulted from the need to be informed about the range of initial solution $\mathrm{pH}$ at which a feasible butanoic acid leaching of galena should commence having preassumed the final $\mathrm{pH}$ and concentration of dissolved zinc expected at the end of the leaching process. It is expected that the model would guide extractive metallurgists in achieving maximum yield through the application of the optimum initial $\mathrm{pH}$ of the leaching solution. This derivation is in furtherance of the previous work [22].

\section{MODEL}

During the leaching process, the ore was assumed to be stationary in the reaction vessel and contains the un-leached lead and zinc as part of reaction remnants. The ore was attacked by hydrogen ions from butanoic acid within the liquid phase, and in the presence of oxygen.

\subsection{Model Formulation}

Results from experimental work [22] carried out at SynchroWell Research Laboratory, Enugu were used for the model derivation. These results are as presented in Table 1.

Computational analysis of these experimental results [22] shown in Table 1, resulted to Table 2 which indicate that;

$$
\begin{aligned}
\mathrm{e}^{[\mathrm{N}(\gamma / \alpha)]} & ={ }^{3} \sqrt{\mathrm{Zn}} \quad \text { (approximately) } \\
\mathrm{e}^{[\mathrm{N}(\gamma / \alpha)]} & =(\mathrm{Zn})^{1 / 3}
\end{aligned}
$$

Taking the natural Log of both sides of equation (9)

$$
\begin{aligned}
\mathrm{N}(\gamma / \alpha) & =\ln \left[(\mathrm{Zn})^{1 / 3}\right] \\
(\gamma / \alpha) & =\left(\frac{\ln \left[(\mathrm{Zn})^{1 / 3}\right]}{\mathrm{N}}\right) \\
(\alpha / \gamma) & =\left(\frac{\mathrm{N}}{\ln \left[(\mathrm{Zn})^{1 / 3}\right]}\right)
\end{aligned}
$$

Introducing the value of $\mathrm{N}$ into equation (12) reduces it to;

$$
\alpha=\left(\frac{1.4 \gamma}{\ln \left[(\mathrm{Zn})^{1 / 3}\right]}\right)
$$


Where

$\mathrm{N}=1.4$ (Dissolution coefficient of zinc in butanoic acid) determined in the experiment [22].

$\alpha=$ Initial $\mathrm{pH}$ of the butanoic acid leaching solution just before the leaching process started.

$\gamma=$ Final $\mathrm{pH}$ of the butanoic acid leaching solution at time $\mathrm{t}$.

$\mathrm{Zn}=$ Concentration of dissolved $\mathrm{Zn}$ during the leaching process $(\mathrm{mg} / \mathrm{kg})$

Equation (13) is the derived model.

Table 1. Variation of the initial and final $\mathrm{pH}$ of the butanoic acid leaching solution with the concentration of dissolved Zinc [22].

\begin{tabular}{|c|c|c|}
\hline$(\gamma)$ & $(\alpha)$ & Zn $(\mathrm{mg} / \mathrm{kg})$ \\
\hline 3.98 & 3.80 & 79.96 \\
4.25 & 4.08 & 77.34 \\
4.33 & 4.24 & 72.24 \\
4.41 & 4.36 & 72.02 \\
4.50 & 4.46 & 71.96 \\
4.61 & 4.55 & 71.22 \\
4.63 & 4.60 & 68.64 \\
4.72 & 4.67 & 64.68 \\
4.84 & 4.81 & 64.42 \\
4.86 & 4.83 & 64.22 \\
\hline
\end{tabular}

Table 2. Variation of $\mathrm{e}^{\mathrm{N}(\gamma / \alpha)}$ with ${ }^{3} \sqrt{\mathrm{Zn}}$.

\begin{tabular}{|c|l|l|l|}
\hline$(\gamma / \alpha)$ & $\mathrm{N}(\gamma / \alpha)$ & $\mathrm{e}^{\mathrm{N}(\gamma / \alpha)}$ & $\sqrt[3]{\mathrm{Zn}}$ \\
\hline 1.0474 & 1.4664 & 4.3336 & 4.3082 \\
1.0417 & 1.4584 & 4.2991 & 4.2606 \\
1.0212 & 1.4297 & 4.1774 & 4.1648 \\
1.0115 & 1.4161 & 4.1210 & 4.1606 \\
1.0090 & 1.4126 & 4.1066 & 4.1594 \\
1.0132 & 1.4185 & 4.1309 & 4.1451 \\
1.0065 & 1.4091 & 4.0923 & 4.0944 \\
1.0107 & 1.4150 & 4.1165 & 4.0141 \\
1.0062 & 1.4087 & 4.0906 & 4.0087 \\
1.0062 & 1.4087 & 4.0906 & 4.0046 \\
\hline
\end{tabular}




\section{BOUNDARY AND INITIAL CONDITION}

Iron oxide ore was placed in cylindrical flask $30 \mathrm{~cm}$ high containing leaching solution of hydrogen peroxide. The leaching solution is non flowing (stationary). Before the start of the leaching process, the flask was assumed to be initially free of attached bacteria and other micro organism. Initially, the effect of oxygen on the process was assumed to be atmospheric. In all cases, weight of iron oxide ore used was $5 \mathrm{~g}$. The initial $\mathrm{pH}$ range of leaching solutions used; 3.80-4.83 and leaching time of $2 \mathrm{hrs}$ (120 minutes) were used for all samples. A constant leaching temperature of $25^{\circ} \mathrm{C}$ was used. Hydrogen peroxide concentration at $0.27 \mathrm{~mol} /$ litre and average ore grain size; $150 \mu \mathrm{m}$ were also used. Details of the experimental technique are as presented in the report [22].

The leaching process boundary conditions include: atmospheric levels of oxygen (considering that the cylinder was open at the top) at both the top and bottom of the ore particles in the gas and liquid phases respectively. A zero gradient was assumed for the liquid scalar at the bottom of the particles and for the gas phase at the top of the particles. The sides of the particles were assumed to be symmetries.

\section{MODEL VALIDATION}

The formulated model was validated by calculating the deviation of the model-predicted initial $\mathrm{pH}$ from the corresponding experimental $\mathrm{pH}$ values.

The deviation recorded is believed to be due to the fact that the surface properties of the ore and the physiochemical interactions between the ore and leaching solution which were found to play vital roles during the leaching process [22] were not considered during the model formulation. It is expected that introduction of correction factor to the predicted initial $\mathrm{pH}$, gives exactly the experimental initial $\mathrm{pH}$ values.

Deviation (Dn) (\%) of model-predicted initial $\mathrm{pH}$ values from those of the experiment is given by

$D n=\left(\frac{P_{I}-E_{I}}{E_{I}}\right) \times 100$

Where $\quad \mathrm{P}_{\mathrm{I}}=$ Predicted initial $\mathrm{pH}$ values

$\mathrm{E}_{\mathrm{I}}=$ Experimental initial $\mathrm{pH}$ values

Since correction factor $(\mathrm{Cr})$ is the negative of the deviation,

$\mathrm{Cr}=-\mathrm{Dn}$

Substituting equation (14) into equation (15) for Dn, $\mathrm{Cr}=-100\left(\frac{\mathrm{P}_{\mathrm{I}}-\mathrm{E}_{\mathrm{I}}}{\mathrm{E}_{\mathrm{I}}}\right)$ 
It was observed that addition of the corresponding values of $\mathrm{Cr}$ from equation (16) to the modelpredicted initial $\mathrm{pH}$ gave exactly the corresponding experimental initial $\mathrm{pH}$ values [22].

\section{RESULTS AND DISCUSSION}

The derived model is equation (13). An ideal comparison of the initial $\mathrm{pH}$ as obtained from experiment and as predicted by the model for the purpose of testing the validity of the model is achieved by considering the $\mathrm{R}^{2}$ values (coefficient of determination). The values of the correlation coefficient, $\mathrm{R}$ calculated from the equation;

$$
\mathrm{R}=\sqrt{ } \mathrm{R}^{2}
$$

using the r-squared values (coefficient of determination) from Figs. 1 and 2 show a better correlation (0.9565) with model-predicted initial solution $\mathrm{pH}$ than that obtained from experiment (0.9300). This suggests that the model predicts more accurate, reliable and ideal initial solution $\mathrm{pH}$ than the actual experiment despite its deviations from the experimental values.
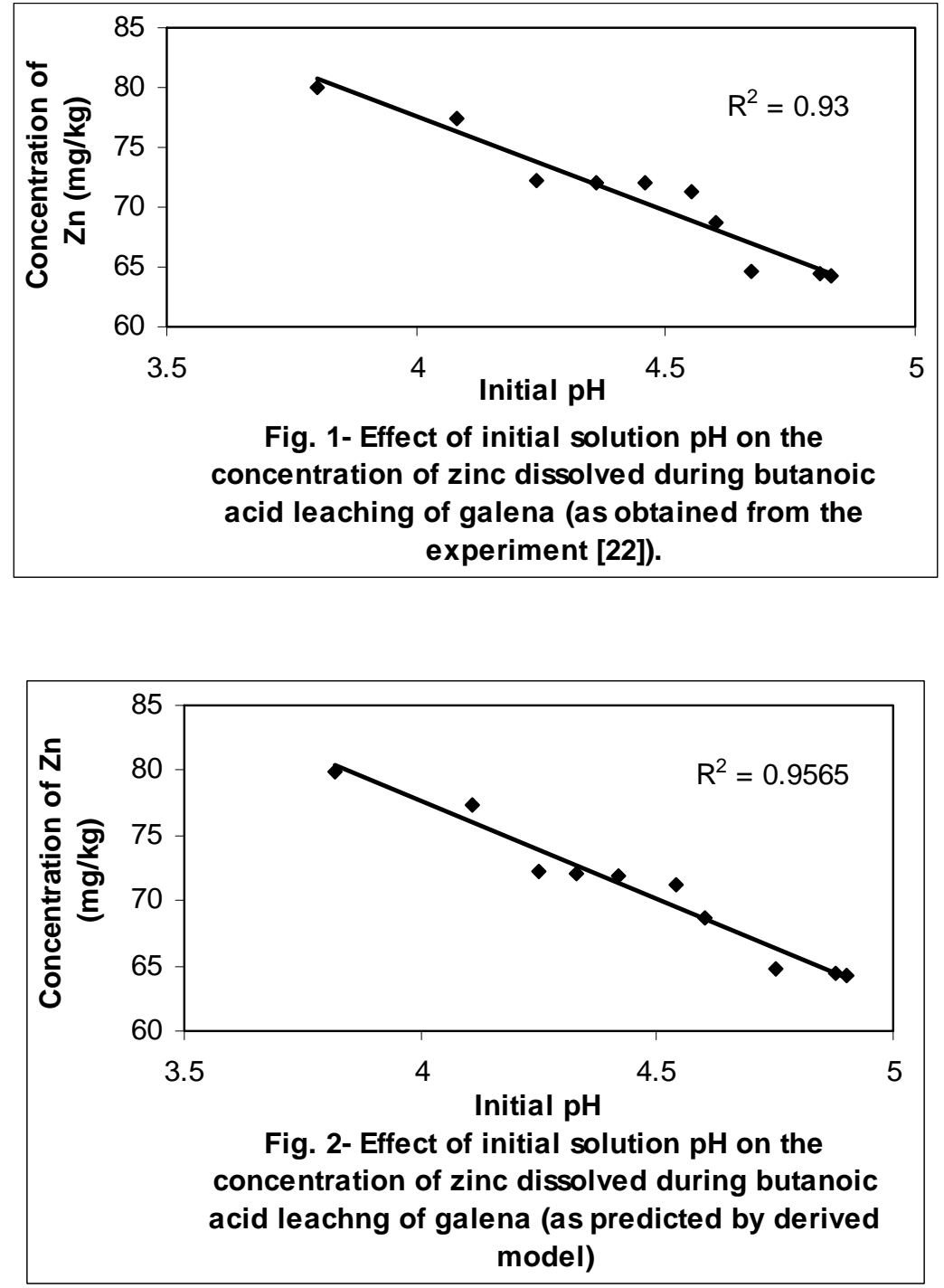
Comparison between Figs. 3 and 4 also show that the final solution $\mathrm{pH}$ from experiment has a better correlation $(0.9954)$ with the initial $\mathrm{pH}$ predicted by the model than that obtained from the relationship between experimental values of the final and initial solution $\mathrm{pH}(0.9926)$.

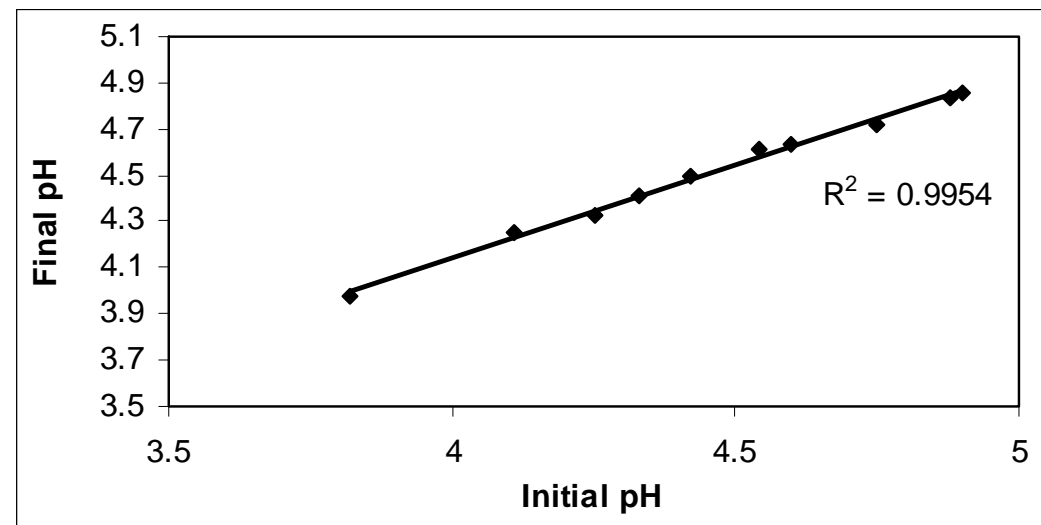

Fig. 3- Effect of initial solution pH (from model) on the final $\mathrm{pH}$ (as obtained from the experiment [22])

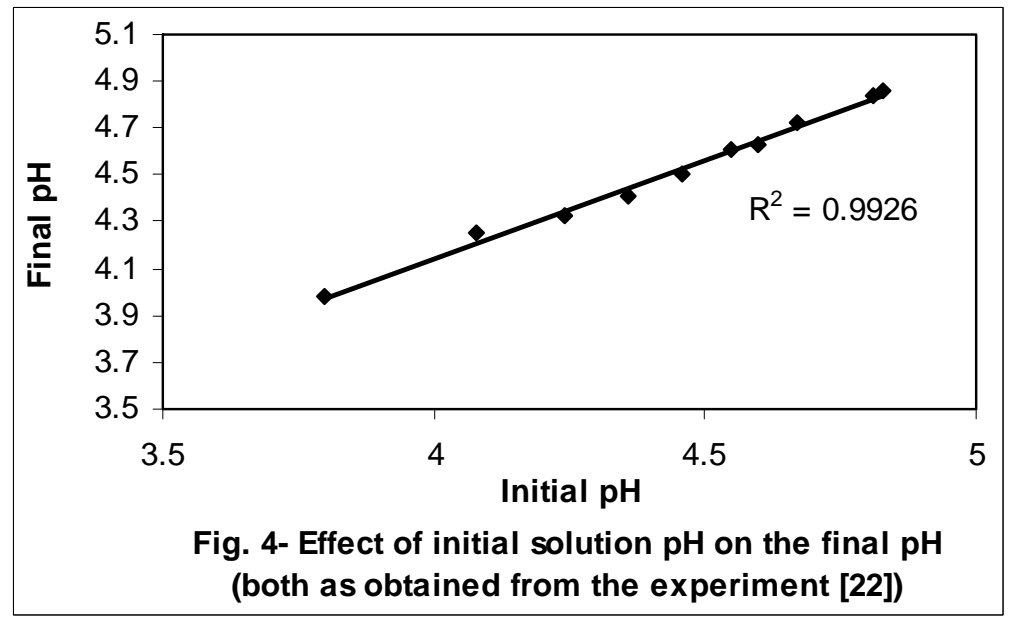

However, Fig. 5 shows very close alignment of the curves from model-predicted values of the initial $\mathrm{pH}(\mathrm{MoD})$ and that from the corresponding experimental values (ExD). The degree of alignment of these curves is indicative of the proximate agreement between both experimental and model-predicted initial solution $\mathrm{pH}$. The validity of the model is believed to be rooted on equation (8) where both sides of the equation are approximately equal to 4 . Table 2 also agrees with equation (8) following the values of $\mathrm{e}^{\mathrm{N}(\gamma / \alpha)}$ and ${ }^{3} \sqrt{\mathrm{Zn}}$ evaluated following statistical and computational analysis carried out on the experimental results in Table1.

Based on the foregoing, the model is believed to be very valid as a predictive tool. Furthermore, Fig. 6 shows insignificant positive and negative deviations of the mode-predicted initial $\mathrm{pH}$ from the corresponding experimental values. It was also shown in Fig.6 that the positive and negative deviations of the model-predicted initial $\mathrm{pH}$ values from those of the experiment were less than $2 \%$ which is quite within the acceptable deviation limit of experimental results. The positive and 
negative deviations (of the model-predicted initial $\mathrm{pH}$ ) from the actual experimental values show undulating relationship (as in Fig.6) with the model-predicted initial $\mathrm{pH}$.
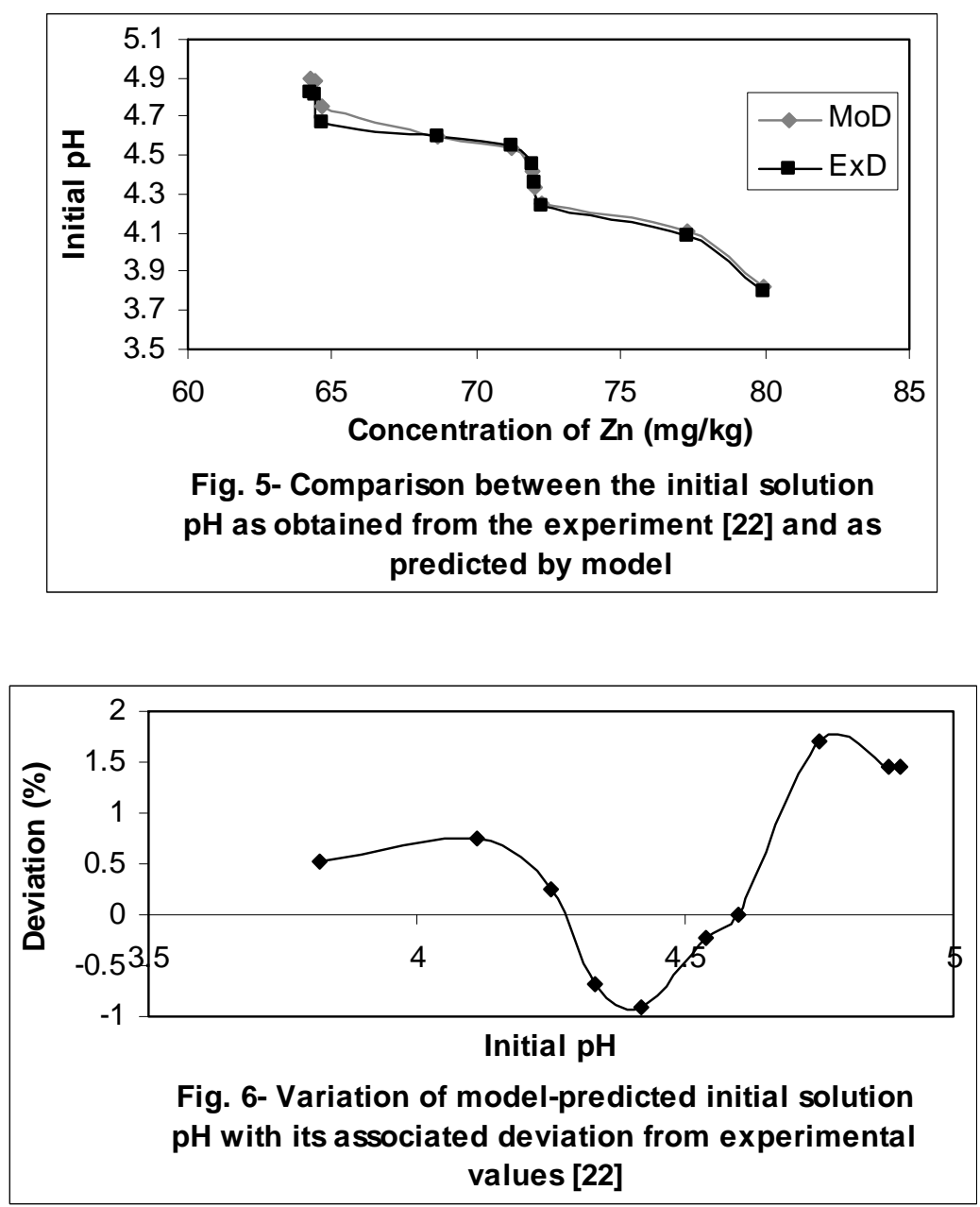

The least and highest magnitude of deviation of the model-predicted initial solution $\mathrm{pH}$ (from the corresponding experimental values) are $-0.22 \%$ and $1.71 \%$ which correspond to initial solution $\mathrm{pH} 4.54$ and 4.75 respectively. Correction factor for the model-predicted initial solution $\mathrm{pH}$ (shown in Fig.7) similarly shows an undulating relationship with model-predicted initial $\mathrm{pH}$. However, the orientation of this curve is opposite that of the deviation values of model-predicted initial $\mathrm{pH}$ (Fig.6). This is because correction factor is the negative of the deviation as shown in eqns. (15) and (16). It is believed that the correction factor takes care of the effects of the surface properties of the ore and the physiochemical interaction between the ore and the leaching solution which (affected experimental results) were not considered during the model formulation.

Based on the foregoing, Fig.7 indicates that a correction factor of -0.22 and $1.71 \%$ make up for the least and highest deviation of 0.22 and $-1.71 \%$ resulting from application of initial solution $\mathrm{pH} 4.54$ and 4.75 respectively. It is pertinent to state that the actual deviations are just the 
modulus of the values. The role of the sign attached to the values is just to show when the deviation is surplus or deficit.

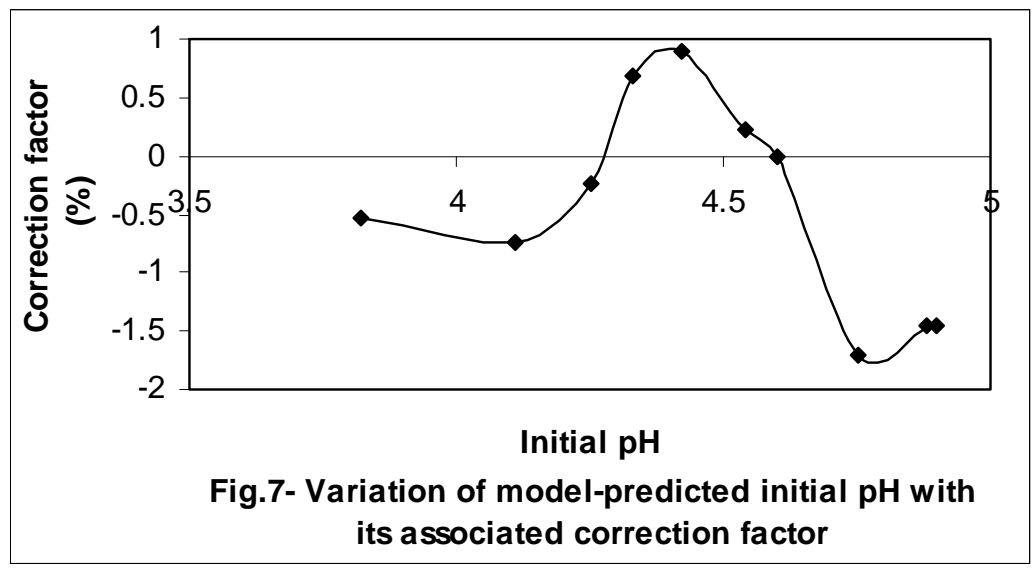

\section{CONCLUSION}

The model predicts the initial solution $\mathrm{pH}$ at pre-assumed final solution $\mathrm{pH}$ and concentration of dissolved zinc during leaching of Ishiagu (Nigeria) galena in butanoic acid solution. This prediction could be done during the leaching process providing the expectant final $\mathrm{pH}$ of the solution and concentration of dissolved zinc are known. The validity of the model is believed to be rooted in the expression $\mathrm{e}^{\mathrm{N}(\gamma / \alpha)}=\sqrt[3]{\mathrm{Zn}}$ where both sides of the expression are approximately equal to 4 . The respective deviation of the model-predicted initial solution $\mathrm{pH}$ value from that of the corresponding experimental value is less than $2 \%$ which is quite within the acceptable deviation limit of experimental results.

\section{ACKNOWLEDGEMENT}

The author thanks Dr. Ekeme Udoh and Pearl Bassey, modelling experts at Linkwell Modelling Centre Calabar for his technical inputs. The management of SynchroWell Nig. Ltd. Enugu is also appreciated for permitting and providing the experimental data used in this work.

\section{REFERENCES}

[1] Bogue, R.G., Reynolds, R.R. (1951) Report on the Lead-Zinc Deposits of the Abakiliki District Ogoja Province, Nigeria (unpublished manuscripts).

[2] Udum, J.T., (1998) Beneficiation Studies of Ishiagu Pb - Zn ore Trans SME/AIME 24(1): 500

[3] Okoro, C.C. (2004) Hydrometallurgical Extraction of Lead from Ishiagu Galena, B. Eng. Project Materials and Metallurgical Engineering Dept., Federal University of Technology Owerri.

[4] Onyemaobi, O. O.(1990) Evaluation of Flotation Performance of Nigeria's Sphalente (ZnS) 
Without Activation by copper. Ife Journal of Tech. 2(2):21-25.

[5] Onyemaobi, O.O. Anyakwo, C.N. (1996) Factors Affecting the Performance of Nigeria's Lead and Zinc Ores for Industrial Usage JSET, 3(1): 46.

[6] Onyemaobi, O.O. (1990) Flotability of Ishiagu Galena as Raw Materials for Smelters. Nigeria Journal of Applied Science 8 (1): 93-101.

[7] Agha, U.H. (1990) Role of PH on Flotation of Sphalerite from Ishiagu Lead-Zinc Ore, Nigeran Journal of Applied Science 2 (2):4-6.

[8] Olubambi, P.A, Ndlovu, S., Potgieter, H., Borode, J.O. (2007) Effects of Ore Mineralogy on the Microbial Leaching of Low Grade Complex Sulphide Ore. Hydrometallurgy 86: 96-104.

[9] Olubami, P.A., Borode, J.O., Ndlovu, S. (2006) Sulphuric Acid Leaching of Zinc and Copper from Nigerian Complex Sulphide Ore in the Presence of Hydrogen Peroxide. Journal of the Southern African Inst. Of Mining and Metallurgy 106: 765-769.

[10] Nwoye, C. I. (2008) Ph.D Thesis, Metallurgical and Materials Engineering Department, Federal University of Technology, Owerri,178.

[11] Haver, F.P., Wong, M. M. (1971) Recovering Elemental Sulfur from Non-Ferrous Minerals. Rep.Invest. U.S Bur. Mines 7474,20 in Orlowska L and Golab B; Microbial Leaching of Blende Flotation Concentrate using Acidithiobacillus Ferrooxidans and Acidithiobacillus Thiooxidans Physicochemical Problems of Mineral processing 37,1990,58.

[12] Sklodowska, R. (1990) Microbial Leaching of Blende Flotation Concentrate using Acidithiobacillus Ferrooxidans and Acidithiobacillus Thiooxidans; Physico Chemical Problems of Mineral Processing 37:58.

[13] Cwalina, W. (1994) Microbial Leaching of Blende Flotation Concentrate using Acidithiobacillus Ferrooxidans and Acidthiobacillus Thiooxidans Physicochemical Problems of Mineral Processing 37:58.

[14] Makita, M., Esperon, M., Pereyra, B., Lopez, A., Orrantia, E. (2004) Reduction of Arsenic Content in a Complex Galena Concentrate by Acidithiobacillus Ferrooxidans; BioMed Central Biotechnology, 4:22 doi: 10.1186/1472-6750-6750-4-22 (published on line)

[15] Williamson, S., Rimstidt, M., Smith, T., Schumate, H. (2005) Rates of Leaching in Single and Two Phase System. Min. mag., 3

[16] Prosper, I. (2005) Acid leaching of lead sulphide, J. Med. Central. 3(4):13-16.

[17] Rawlings, D.E. (2005) Characteristics and Adaptability of Iron and Sulphur Oxidizing Microorganisms Used for the Recovery of Metals from Minerals and Their Concentrates, Bio Med Central, 4:13 doi 10:1186/1475-2859-4-13 (published on line)

[18] Dutrizac, J.E. (1986) The Dissolution of Galena in Ferric Chloride Media, Metallurgical Transactions B, 17B: 77.

[19] Seon-Hyo, K. K., Henein, H., Warren, G.W (1986) An Investigation of the Thermodynamics and Kinetics of the Ferric Chloride Brine Leaching of Galena Concentrate. Metallurgical Transaction B, 17B:26.

[20] Dix, R.B., Hendrix, J. L. (1986) Kinetics of $\mathrm{Cl}_{2}-\mathrm{O}_{2}$ Leaching of Lead-Zinc Flotation Concentrates. University of Nevada Reno, 89557

[21] Pinches, A. (1975) Bacterial Leaching of an Arsenic Bearing Sulphide Concentrate. The Institute of Mining and Metallurgy, England, 34.

[22] Nwoye, C. I. (2008) SynchroWell Research Work Report, DFM Unit, No 2008600, 15-28. 